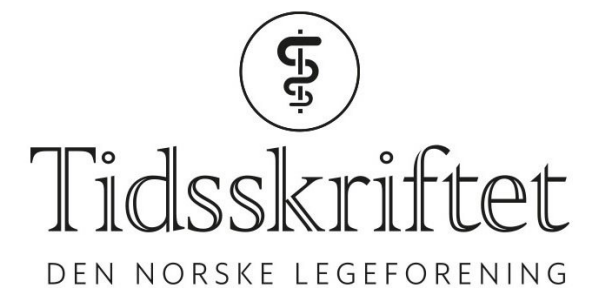

DEN NORSKE LEGEFORENING

\title{
Blivende psykiatere bør få veiledning i både psykodynamisk og kognitiv terapi
}

DEBATT

\section{ERIK FALKUM}

E-post: erik.falkum@medisin.uio.no

Erik Falkum er professor ved Institutt for klinisk medisin, Universitetet i Oslo og konstituert avdelingsleder ved avdeling for forskning og utvikling, Klinikk psykisk helse og avhengighet, Oslo universitetssykehus.

Forfatter har fylt ut ICMJE-skjemaet og oppgir ingen interessekonflikter.

Veiledningen i psykoterapi for utdanningskandidater i psykiatri er i endring. Et utvalg oppnevnt av Norsk psykiatrisk forening foreslår at den fremtidige veiledningen bør bestå av to obligatoriske bolker i henholdsvis psykodynamisk og kognitiv terapi, samt av en valgfri bolk i psykodynamisk terapi, kognitiv atferdsterapi eller gruppeterapi.

Hittil har den treårige psykoterapiveiledningen bestått av to år obligatorisk såkalt grunnleggende veiledning med fokus på forholdet mellom lege og pasient med utgangspunkt i psykodynamisk teori og ett år valgfri veiledning i enten psykodynamisk psykoterapi, kognitiv atferdsterapi eller gruppeterapi. Ordningen har medført at mange utdanningskandidater har fått all sin veiledning innenfor den psykodynamiske tradisjonen, ettersom både den grunnleggende veiledningen og veiledningen i gruppeterapi har vært basert på denne tradisjonen.

Kolleger med klinisk erfaring fra distriktpsykiatriske sentre, som behandler hele det store mangfoldet av pasienter, vet at verken kognitiv atferdsterapi eller psykodynamisk terapi eller en hvilken som helst annen tilnærming passer for alle på alle tidspunkter. Siden vi er forpliktet til å gi alle et tilbud, må dette bety at det er en åpenbar fordel for psykiateren å beherske flere psykoterapimodeller.

Det finnes ingen "grand unified theory» i psykoterapifeltet. Når vi for eksempel skal forklare fremveksten av en depressiv lidelse, kan hovedvekten legges på sårbarhet etablert i samspillet med barndommens omsorgspersoner og sårbarhetens konsekvenser for nåtidige relasjoner (som i psykoanalytisk terapi), på negative automatiske tanker (som i kognitiv atferdsterapi), på manglende eller vanskelige nåtidige relasjoner (som i interpersonlig terapi) eller på sparsom eller ensidig negativ tilbakemelding (som i atferdsterapi) $(1,2)$. Dette mangfoldet er en stor utfordring for utdanningskandidater, som i løpet av relativt kort tid skal bli fortrolige med mange nye begreper og et språk de kan anvende i møte med pasientene. Psykoterapiveiledningen har avgjørende betydning for denne læringsprosessen. 


\section{Fellesfaktorer og spesifikke terapeutiske intervensjoner}

Størstedelen av moderne psykoterapiforskning unders $\emptyset$ ker virkningen av spesifikke intervensjoner, men det har vært vanskelig å vise at én behandling som er antatt virksom for en konkret lidelse, er klart bedre enn andre. Generelt ser det ut til at ulike behandlinger er omtrent like effektive. Samtidig er det i tillegg til de anvendte metodene en rekke faktorer som er virksomme i alle former for psykoterapi: den terapeutiske alliansen, korrektiv emosjonell erfaring, terapeutens oppmerksomhet, varme, innlevelse og bekreftelse og en akseptabel orientering om behandlingsmetodens grunnlag. Listen over disse fellesfaktorene er lang, og den samlede effekten av dem er vanskelig å bestemme, blant annet fordi det finnes en rekke interaksjoner mellom fellesfaktorer og spesifikke intervensjoner $(1,3)$. Disse fellesfaktorene er et sentralt veiledningstema.

\section{Ulike problemer, ulike pasienter, ulike terapeuter}

Behandlingssituasjoner er like eller ulike ikke bare på klinisk-diagnostisk grunnlag, men også fordi både pasienter og terapeuter er forskjellige. Det er vist at terapeuter med god relasjonell kompetanse generelt gjør det bedre enn kolleger som strever med å etablere og opprettholde en bærende relasjon (4, 5). Pasienter med samme diagnose er også forskjellige. De har forskjellig historie, forskjellige temperaments- og karakterprofiler, forskjellige måter å tenke på, forskjellig affektbevissthet osv. En rekke av disse forskjellene må antas å påvirke hvor tilgjengelige de er for ulike terapimodeller. Personer som primært er opptatt av å bli kvitt et plagsomt symptom, vil i utgangspunktet kanskje profitere mest på en direktiv og konkret tilnærming (som kognitiv atferdsterapi), mens utpreget introspektive personer kanskje vil ha bedre nytte av en eksplorerende terapi (som psykodynamisk terapi). Underveis i behandlingen kan dette endre seg, slik at en pasient som i utgangspunktet er mest opptatt av symptomer, blir mer opptatt av indre prosesser, og kanskje også omvendt.

\section{Psykoterapiveiledning gjennom hele spesialistutdanningen}

Norsk psykiatrisk forening satte i 2015 ned et utvalg som skulle utrede fremtidens psykoterapiundervisning for kommende psykiatere. I høringsrunden etter at utvalget hadde avlevert sin innstilling, sluttet de fleste seg til ad hoc-utvalgets forslag om obligatorisk veiledning i kognitiv atferdsterapi. På Psykiatriveka i 2017 ble forslaget som helhet likevel møtt med betydelig motstand fra veiledere i psykodynamisk psykoterapi. Innvendingene dreide seg $\mathrm{i}$ hovedsak om at de to første årene med såkalt grunnleggende veiledning ville bli borte hvis forslaget ble fulgt. Ad hoc-utvalget skilte ikke eksplisitt mellom grunnleggende og videregående veiledning. Argumentet var at ingen ferske spesialister har fått noe annet enn helt grunnleggende utdanning i psykoterapi. Det er derfor bred enighet om å oppfordre utdanningskandidater til å ta videre utdanning ved de spesifikke psykoterapiinstituttene.

Ideelt sett burde kandidatene få individuell psykoterapiveiledning gjennom hele spesialistutdanningen. Med veiledning i fire år kunne man beholdt det første året med fokus på relasjon og arbeidsallianse, men med et bredere teoretisk grunnlag enn til nå. Den psykodynamiske modellen rommer en viktig del av dette grunnlaget, men det burde etter min oppfatning også inkludert nyere kunnskap innen pedagogikk, sosialpsykologi, kommunikasjonsvitenskap og nevrobiologi. Ad hoc-utvalgets forslag om veiledning i gruppe gjennom hele spesialistutdanningen kan kompensere noe på dette punktet.

\section{Den polariserte debatten hemmer utvikling}

Kognitive terapeuter, som i internasjonal sammenheng for det meste ikke har mottatt noen grunnleggende veiledning om ubevisst motivasjon, forsvarsmekanismer og overføring, m.a.o. den grunnleggende dynamiske veiledningen som vi har i Norge etter gjeldende ordning, har likevel like gode behandlingsresultater som dynamiske terapeuter. Derfor er det vanskelig å begrunne at tap av den grunnleggende individuelle veiledningen vil ha 
«drastiske konsekvenser for norske psykiateres holdning til pasienter og pårørende og deres forståelse av pasienters psykopatologi» (6). Spådommen har ingen støtte i psykoterapiforskningen.

Noen av høringsuttalelsene tegnet karikaturer av den symptomorienterte kognitive terapeuten som en overfladisk skikkelse med en naiv tro på en rasjonell verden, en skikkelse som fornekter ubevisst motivasjon og tror at alle kan helbredes med kortvarige symptomorienterte metoder, bare legen er grei og hyggelig. Selv om det kanskje finnes enkelte slike karikaturer, er en slik påstand unyansert blant annet fordi den ikke skiller mellom den kognitive modellen som teori om psykopatologi og som endringsteori.

De fleste kognitive terapeuter anerkjenner ubevisst motivasjon og dens betydning for fremveksten av psykisk lidelse, samtidig som de mener at endring kan skje ved at ikkeadaptive tankemønstre og defensiv atferd utfordres direkte og systematisk. Menneskesynet er med andre ord kanskje ikke så grunnleggende forskjellig som det blir hevdet.

Polemikkens enten-eller-diskurs virker sjelden eller aldri samlende. Det må derfor være en sentral ambisjon å legge den polariserte debatten til side slik at samtalen blir åpnende. Produktive forhandlinger må starte ved å kartlegge det som forener, ikke det som skiller. Slik kartlegging klargjør felles verdier og legger til rette for gjensidig anerkjennelse. Først når uenige parter opplever respekt, er det grunnlag for å tenke åpent om egne og andres styrker og svakheter.

Både den direktive og den eksplorerende tilnærmingen kan være den beste for noen pasienter i noen kliniske situasjoner. Den dynamiske tilnærmingen kan trolig tjene på å gi mer plass til de konkrete symptomene, mens den kognitive tilnærmingen kan tjene på å veve overføringsperspektivet inn i det terapeutiske arbeidet.

Hvordan kan man fremme dialogen om styrker og svakheter og om det som forener og det som skiller de to tilnærmingene? For det første kan gruppeveiledningene gis i fellesskap med veiledere fra begge tradisjoner til stede. For det andre kan to av bolkene i utdanningen av veiledere bli felles og rette oppmerksomheten mot fellesfaktorer og mot arbeidsalliansens kjennetegn i de to retningene.

\section{LITTERATUR:}

1. Wampold BE. The great psychotherapy debate. models, methods, and findings. Mahwah, New Jersey: Lawrence Erlbaum Associates, 2001.

2. Falkum E, Olavesen B, Hytten K. Problemet med mangfoldet av psykoterapeutiske skoler. Tidsskr Nor Psykol foren 2015; 52:314- 20.

3. Hofman SG, Weinberger J. red. The art and science of psychotherapy. New York: Routledge, Taylor \& Francis Group, 2007.

4. Schöttke H, Flückiger C, Goldberg SB et al. Predicting psychotherapy outcome based on therapist interpersonal skills: A five-year longitudinal study of a therapist assessment protocol. Psychother Res 2017; 27: 642 - 52. [PubMed][CrossRef]

5. Nissen-Lie HA, Monsen JT, Ulleberg P et al. Psychotherapists' self-reports of their interpersonal functioning and difficulties in practice as predictors of patient outcome. Psychother Res 2013; 23: 86 104. [PubMed][CrossRef]

6. Vaglum P. Høringssvar til Ad hoc-utvalgets innstilling om psykoterapiveiledningen. Oslo: Norsk psykiatrisk forening, 2016.

Publisert:3. september 2018. Tidsskr Nor Legeforen. DOI: 10.4045/tidsskr.18.0332

Mottatt 16.4.2018, første revisjon innsendt 2.5.2018, godkjent 3.5.2018.

(C) Tidsskrift for Den norske legeforening 2020. Lastet ned fra tidsskriftet.no 